\title{
Characterization of the $\mathrm{K}^{+}$-channel-coupled adenosine receptor in guinea pig atria
}

\author{
H. Tawfik-Schlieper, K.-N. Klotz, V. A. W. Kreye ${ }^{1}$, and U. Schwabe \\ Pharmakologisches Institut der Universität, Im Neuenheimer Feld 366 \\ 1 II. Physiologisches Institut der Universität, Im Neuenheimer Feld 326, D-6900 Heidelberg, Federal Republic of Germany
}

\begin{abstract}
Summary. In the present work we studied the pharmacological profile of adenosine receptors in guinea pig atria by investigating the effect of different adenosine analogues on ${ }^{86} \mathrm{Rb}^{+}$-efflux from isolated left atria and on binding of the antagonist radioligand 8-cyclopentyl-1,3-[ $\left[{ }^{3} \mathrm{H}\right]$ dipropylxanthine $\left(\left[{ }^{3} \mathrm{H}\right] \mathrm{DPCPX}\right)$ to atrial membrane preparations. The rate of ${ }^{86} \mathrm{Rb}^{+}$-efflux was increased twofold by the maximally effective concentrations of adenosine receptor agonists. The $\mathrm{EC}_{50}$-values for 2-chloro- $\mathrm{N}^{6}$-cyclopentyladenosine (CCPA), R-N ${ }^{6}$-phenylisopropyladenosine (R-PIA), 5'-Nethylcarboxamidoadenosine (NECA), and S-N ${ }^{6}$-phenylisopropyladenosine (S-PIA) were 0.10, 0.14, 0.24 and $12.9 \mu \mathrm{M}$, respectively. DPCPX shifted the R-PIA concentration-response curve to the right in a concentration-dependent manner with a $\mathrm{K}_{\mathrm{B}}$-value of $8.1 \mathrm{nM}$, indicating competitive antagonism. $\left[{ }^{3} \mathrm{H}\right] \mathrm{DPCPX}$ showed a saturable binding to atrial membranes with a $B_{\max }$-value of $227 \mathrm{fmol} / \mathrm{mg}$ protein and a $\mathrm{K}_{\mathrm{D}}$-value of $1.3 \mathrm{nM}$. Competition experiments showed a similar potency for the three agonists CCPA, R-PIA and NECA. S-PIA is 200 times less potent than R-PIA. Our results suggest that the $\mathrm{K}^{+}$channel-coupled adenosine receptor in guinea pig atria is of an $A_{1}$ subtype.
\end{abstract}

Key words: $A_{1}$ Adenosine receptors $-K^{+}$-channels Atria - Radioligand binding $-{ }^{86} \mathrm{Rb}^{+}$-efflux

\section{Introduction}

Adenosine exerts negative inotropic, chronotropic and dromotropic effects in the heart (Drury and Szent-Györgyi 1929; James 1965; Endoh et al. 1983; Evans et al. 1982). In atrial trabeculae it increases the resting membrane potential and decreases the action potential duration (Johnson and Mc Kinnon 1956; Hollander and Webb 1957; De Gubareff and Sleator 1965). Electrophysiological experiments on atrial myocytes and measurements of ${ }^{42} \mathrm{~K}^{+}$-efflux in atrial preparations refered this effect to a receptor-mediated stimulation of the potassium conductance in atrial membranes (Belardinelli and Isenberg 1983; Jochem and Nawrath 1983; West and Belardinelli 1985). These authors suggested that adenosine stimulates the acetylcholine sensitive potassium channel. This adenosine receptor-mediated effect was postu-

Abbreviations: CCPA, 2-chloro- $\mathrm{N}^{6}$-cyclopentyladenosine; DPCPX, 8-cyclopentyl-1,3-dipropylxanthine; NECA, 5'-N-ethylcarboxamidoadenosine; PIA, $\mathrm{N}^{6}$-phenylisopropyladenosine

Send offprint requests to $\mathrm{H}$. Tawfik-Schlieper at the above address lated to be the mechanism of the negative inotropic action of adenosine in guinea pig atria without altering CAMP or cGMP levels (Endoh et al. 1983; Brückner et al. 1985). Several studies showed that a G-protein is involved in the coupling between adenosine receptor and potassium channel in atrial cardiac preparations (Böhm et al. 1986; Kurachi et al. 1986) and in mammalian central neurons (Trussell and Jackson 1987). It is still not clear which adenosine receptor subtype mediates the stimulation of the potassium conductance. In the present study we characterized atrial adenosine receptors by investigating the effect of various adenosine derivatives on the ${ }^{86} \mathrm{Rb}^{+}$-efflux in isolated left guinea pig atria and performing binding experiments on atrial membranes with the $A_{1}$ selective antagonist radioligand $\left[{ }^{3} \mathrm{H}\right] 8$ cylopentyl-1,3-dipropylxanthine $\left[{ }^{3} \mathrm{H}\right] \mathrm{DPCPX}$.

\section{Materials and methods}

Materials. $\left[{ }^{3} \mathrm{H}\right] \mathrm{DPCPX}$ and ${ }^{86} \mathrm{Rb}^{+}$were purchased from Amersham Buchler (Braunschweig, FRG). R-PIA, S-PIA and NECA were obtained from Boehringer Mannheim (Mannheim, FRG). CCPA was synthesized according to Lohse et al. (1988).

Efflux experiments. Guinea pigs were killed by a blow on the neck. The hearts were rapidly excised and the left atria were carefully prepared. They were mounted on stainless steel holders and equilibrated for $15 \mathrm{~min}$ at $37^{\circ} \mathrm{C}$ in incubation buffer bubbled with $95 \% \mathrm{O}_{2} / 5 \% \mathrm{CO}_{2}$. The incubation buffer, $\mathrm{pH} 7.2$, had the following composition in $\mathrm{mM}$ : $\mathrm{NaCl} 128, \mathrm{NaHCO}_{3} 14.4, \mathrm{KCl} 4.7, \mathrm{NaH}_{2} \mathrm{PO}_{4} 1.2, \mathrm{MgCl} 1.2$, Na-Ca-EDTA 0.1 , glucose $10, \mathrm{CaCl}_{2} 1.5$. The ${ }^{86} \mathrm{Rb}^{+}$-efflux studies were carried out according to the method of Gerstheimer et al. (1987) with slight modifications. The equilibrated quiescent preparations were incubated for $90 \mathrm{~min}$ in the buffer solution containing ${ }^{86} \mathrm{Rb}^{+}(74 \mathrm{kBq} / \mathrm{ml})$ at $37^{\circ} \mathrm{C}$. The holders with the atria were then placed on rotating shafts of a small motor. The atrial preparations were sequentially dipped in tubes containing $5 \mathrm{ml}$ of the mentioned buffer for $3 \mathrm{~min}$ in each tube. After $24 \mathrm{~min}$ the rate of ${ }^{86} \mathrm{Rb}^{+}$efflux reached a steady state, then increasing concentrations of agonist were added to the buffer solution. In experiments with antagonist the respective concentrations of the antagonist were added to all tubes of an experiment. At the end of the efflux period the tissue wet weight and the residual radioactivity in the tissue was determined and the radioactivity in the effluents was measured. The rate of ${ }^{86} \mathrm{Rb}^{+}$efflux was calculated as described (Gerstheimer et al. 1987). The data are means of at least 6 experiments. 


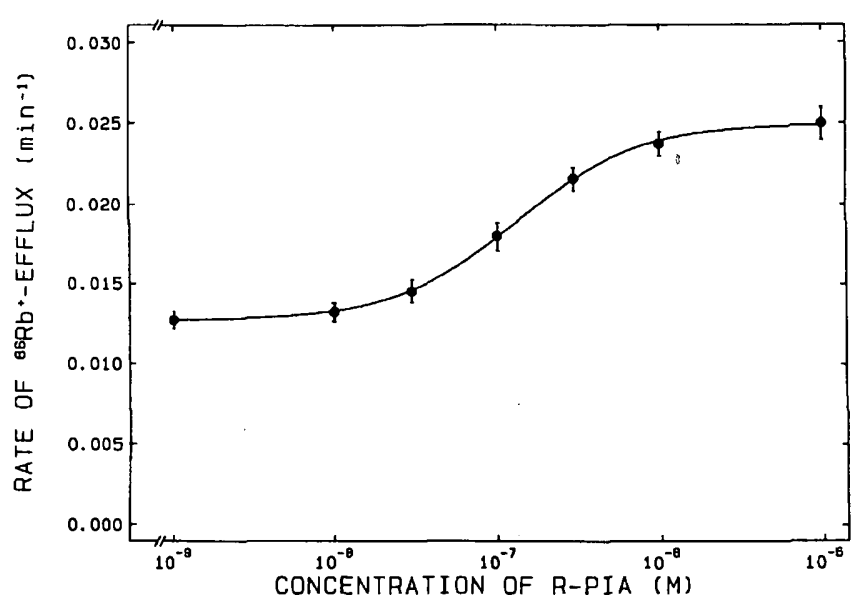

Fig. 1. Effect of R-PIA on the rate of ${ }^{86} \mathrm{Rb}^{+}$-efflux in isolated left guinea pig atria. The concentration of R-PIA was cumulatively increased in the incubation buffer and the effect was studied as described in Methods. The symbols represent the mean value of 6 experiments, the bars are the standard error of the mean

Preparation of atrial membranes. The guinea pig atrial membranes were prepared according to Lohse et al. (1985) with some modifications. The atria were suspended in ice cold $10 \mathrm{mM}$ imidazole $/ 5 \mathrm{mM} \mathrm{MgSO}_{4} / 0.3 \mathrm{M}$ sucrose buffer $(\mathrm{pH} 7)$ and homogenized with a polytron for $20 \mathrm{~s}$ followed by 2 strokes of a glas-teflon potter. The sucrose concentration was then elevated to $0.6 \mathrm{M}$. The homogenate was centrifuged at $21000 \times g$ for $30 \mathrm{~min}$ at $4^{\circ} \mathrm{C}$. The supernatant was diluted with 1.5 volumes $10 \mathrm{mM}$ imidazole $/ 5 \mathrm{mM}$ $\mathrm{MgSO}_{4} / 160 \mathrm{mM} \mathrm{KCl}(\mathrm{pH} 7)$ and centrifuged at $30000 \times g$ for $45 \mathrm{~min}$ at $4^{\circ} \mathrm{C}$. The resulting pellet was resuspended in $50 \mathrm{mM}$ Tris- $\mathrm{HCl}, \mathrm{pH} 7.4$, and stored at $-80^{\circ} \mathrm{C}$. Protein concentrations were measured according to Peterson (1977). The yield of membrane protein was about $0.5 \mathrm{mg} / 10$ atria.

Radioligand binding. The binding of $\left[{ }^{3} \mathrm{H}\right] \mathrm{DPCPX}$ to atrial membranes was carried out at a final protein concentration of $14 \mu \mathrm{g} /$ tube in a total volume of $200 \mu \mathrm{l}$ according to Lohse et al. (1987). In typical experiments $\left(0.2 \mathrm{nM}\left[{ }^{3} \mathrm{H}\right] \mathrm{DPCPX}\right)$ total binding was approximately $200 \mathrm{cpm}$ compared to $40 \mathrm{cpm}$ nonspecific binding. The nonspecific binding was defined by the presence of $10 \mu \mathrm{M}$ R-PIA. In saturation experiments $50 \mu \mathrm{g}$ protein/tube in a total volume of $500 \mu \mathrm{l}$ were used. The incubation was carried out at $12^{\circ} \mathrm{C}$ for $2 \mathrm{~h}$. The reaction was stopped by filtration over Whatman GF/ $B$ filters. The radioactivity was determined by liquid scintillation counting for $10 \mathrm{~min}$.

\section{Results}

\section{Measurement of ${ }^{86} R b^{+}-$efflux}

First we tested the effect of R-PIA on $\mathrm{K}^{+}$conductance by measuring ${ }^{86} \mathrm{Rb}^{+}$-efflux from atrial tissue in presence of increasing concentrations of R-PIA. Figure 1 shows the concentration-response curve of the R-PIA effect on the rate of ${ }^{86} \mathrm{Rb}^{+}$-efflux from guinea pig left atria. R-PIA caused a concentration-dependent increase in the efflux rate. At maximal concentrations the rate of efflux was twice the basal value. The $\mathrm{EC}_{50}$ of R-PIA was $137 \mathrm{nM}$. The effect of various

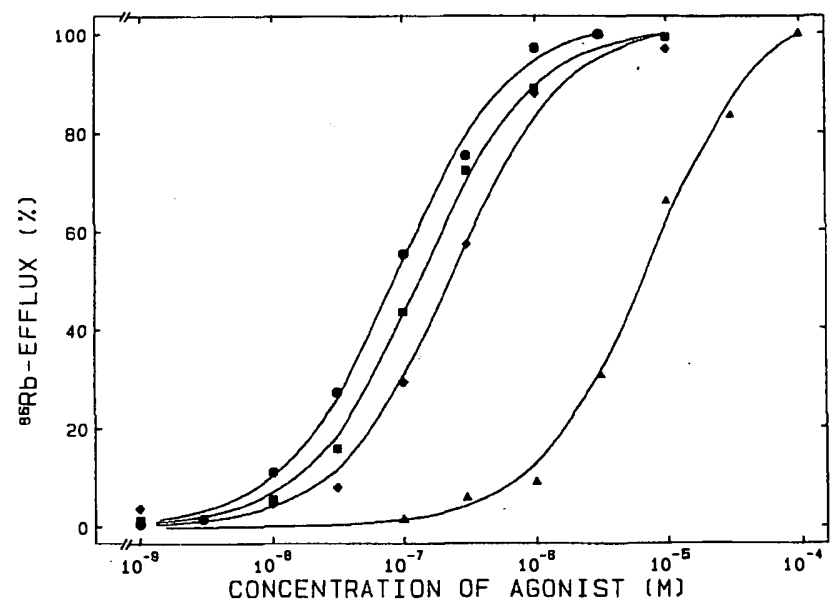

Fig. 2. Effect of different adenosine analogues on the rate of ${ }^{86} \mathrm{Rb}^{+}$ efflux in isolated left guinea pig atria. Data (means of 6 experiments) are expressed as percent of the maximal effect induced by CCPA $(\bullet)$, R-PIA (ם), NECA ( $\bullet$ ), S-PIA (4)

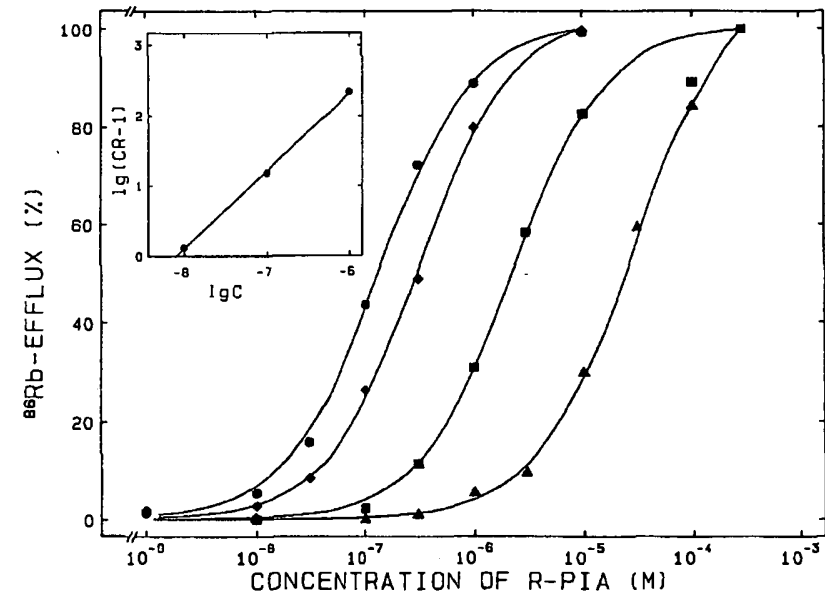

Fig. 3. Effect of the adenosine antagonist DPCPX on R-PIA-stimulated ${ }^{86} \mathrm{Rb}^{+}$-efflux in guinea pig atria. The effect of R-PIA was measured in the absence $(\bullet)$ and the presence of $10 \mathrm{nM}(\diamond), 100 \mathrm{nM}$ (घ) and $1000 \mathrm{nM}(\mathbf{\Delta})$ DPCPX. Data are expressed as percent of the maximal change in ${ }^{86} \mathrm{Rb}^{+}$-efflux caused by R-PIA. Inset: Schild plot of the data. $C=$ molar concentration of DPCPX, $C R=$ ratio of the EC $E_{50}$ values of R-PIA in the presence and absence of DPCPX, $n=6$

adenosine derivatives on the ${ }^{86} \mathrm{Rb}^{+}$-efflux is shown in Fig. 2 and the $\mathrm{EC}_{50}$ values are $103 \mathrm{nM}$ for CCPA, followed by R-PIA (137 nM), NECA (217 nM) and S-PIA (12905 nM). The ${ }^{86} \mathrm{Rb}^{+}$-efflux was stimulated by the PIA-enantiomers in a highly stereoselective manner with R-PIA being about 100 -fold more potent than S-PIA.

The adenosine receptor mediated ${ }^{86} \mathrm{Rb}^{+}$-efflux was then antagonized with DPCPX, which is highly selective for the $A_{1}$ subtype. Figure 3 shows concentration-response curves of R-PIA in the absence and presence of different concentrations of DPCPX. DPCPX caused a concentration-dependent shift of the concentration-response curve to the right. A Schild plot of these data gave a line with a slope of 1.1 and a $\mathrm{K}_{\mathrm{B}}$-value of $8.2 \mathrm{nM}$ for DPCPX. 


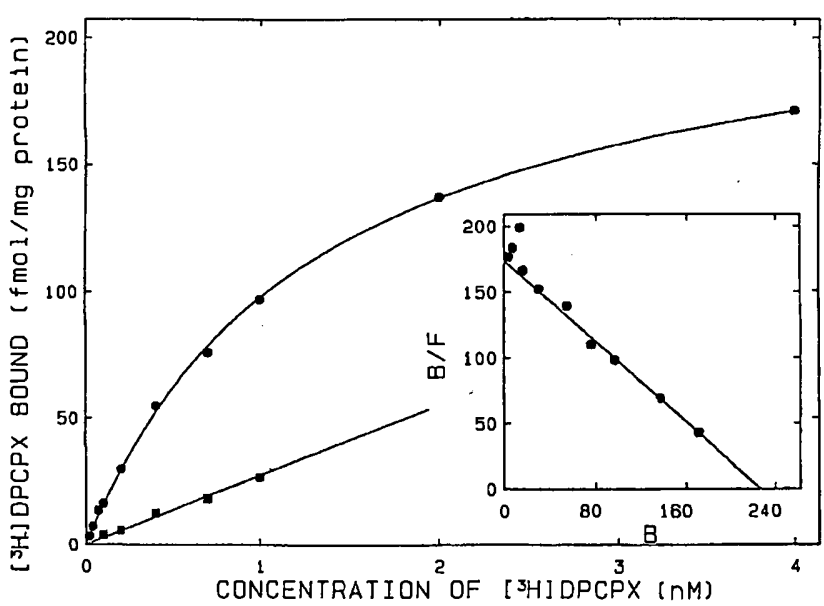

Fig. 4. Saturation of $\left[{ }^{3} \mathrm{H}\right] \mathrm{DPCPX}$ binding to membranes of guinea pig atria. Specific binding ( ), nonspecific binding (ם). Inset: Scatchard plot of the data; $B=\left[{ }^{3} \mathrm{H}\right] \mathrm{DPCPX}$ bound $(\mathrm{fmol} / \mathrm{mg}$ protein), $F=$ concentration of $\left[{ }^{3} \mathrm{H}\right] \mathrm{DPCPX}(\mathrm{nM})$. Computerized curve fitting gave $a B_{\max }$ of $227 \mathrm{fmol} / \mathrm{mg}$ protein and a $K_{D}$ of $1.3 \mathrm{nM}$

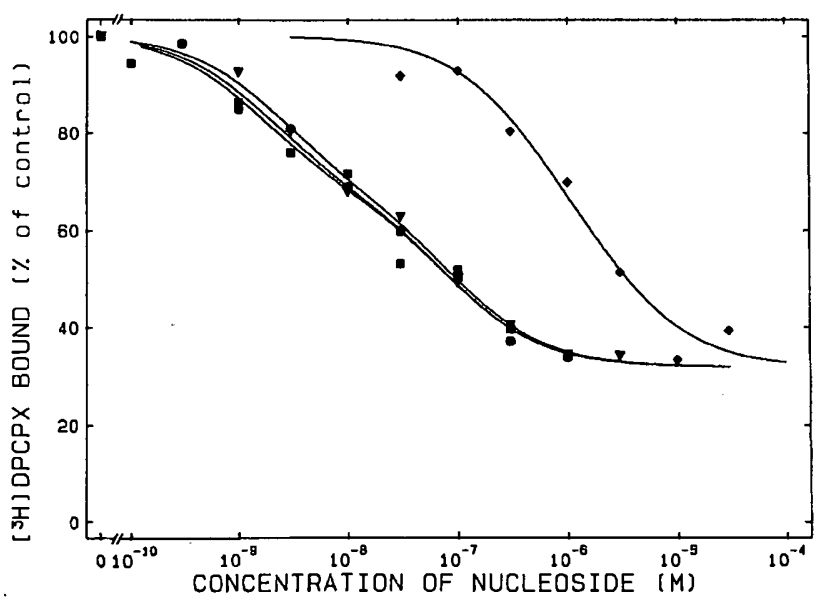

Fig. 5. Competition for $\left[{ }^{3} \mathrm{H}\right] \mathrm{DPCPX}$ binding to guinea pig atrial membranes by adenosine receptor agonists. Membranes were incubated with $0.2 \mathrm{nM}\left[{ }^{3} \mathrm{H}\right] \mathrm{DPCPX}$ in the presence of increasing concentrations of CCPA $(\bullet)$, R-PIA $(\boldsymbol{\square})$, NECA $(\bullet)$ and S-PIA $(\boldsymbol{\Delta})$. Competition curves were simultaneously fitted with the program SCTFIT. The data were best fitted assuming a two side model, and the proportions of receptors in the high and the low affinity state were $48 \%$ and $52 \%$, respectively

\section{Radioligand binding studies}

To further characterize the atrial adenosine receptors we performed radioligand binding experiments on membrane preparations from guinea pig atria. Figure 4 shows a saturation experiment with $\left[{ }^{3} \mathrm{H}\right] \mathrm{DPCPX}$. By non-linear curvefitting of the data a $\mathrm{K}_{\mathrm{D}}$-value of $1.5 \mathrm{nM}$ and a binding capacity of $200 \mathrm{fmol} / \mathrm{mg}$ protein was calculated.

Furthermore, we investigated the pharmacological profile of the receptors by competition with different agonists for $\left[{ }^{3} \mathrm{H}\right] \mathrm{DPCPX}$ binding on atrial membranes (Fig. 5). The biphasic character of the competition curves indicates the presence of two affinity states for the agonists, with one half of the binding sites being in the high affinity state and the other half in the low affinity state. R-PIA is about 200 -fold
Table 1. Effect of different adenosine analogues on the binding of $\left[{ }^{3} \mathrm{H}\right]$ DPCPX to guinea pig atrial membranes and on ${ }^{86} \mathrm{Rb}^{+}$-efflux rate in isolated left guinea pig atria. $K_{H}$ and $K_{L}$ are the $K_{D}$ values of the high and low affinity states for agonist, respectively. The $\mathrm{EC}_{50}$-values for ${ }^{86} \mathrm{Rb}^{+}$-efflux are calculated from $5-6$ experiments and confidence limits are given in brackets. The $\mathrm{EC}_{50}$-values of CCPA, R-PIA and NECA are not significantly different

\begin{tabular}{lccc}
\hline & \multicolumn{2}{l}{ Radioligand binding } & ${ }^{86} \mathrm{Rb}^{+}$-Efflux \\
\cline { 2 - 3 } & $\mathrm{K}_{\mathrm{H}}(\mathrm{nM})$ & $\mathrm{K}_{\mathrm{L}}(\mathrm{nM})$ & $\mathrm{EC}_{50}(\mathrm{nM})$ \\
\hline CCPA & 1.2 & 62 & $103(37-290)$ \\
R-PIA & 1.4 & 61 & $137(85-222)$ \\
NECA & 1.8 & 68 & $217(157-301)$ \\
S-PIA & 331 & 1786 & $12905(6336-26286)$ \\
\hline
\end{tabular}

more potent than S-PIA. The competition curves of the three agonists CCPA, R-PIA and NECA are almost superimposable. Table 1 summarizes the functional and the binding data. It is obvious that the $\mathrm{EC}_{50}$ values from the efflux experiments are in the same concentration range as the $\mathrm{K}_{\mathrm{D}^{-}}$ values for the low affinity state.

\section{Discussion}

Adenosine exhibits a negative inotropic effect on the heart (Hollander and Webb 1957; De Gubareff and Sleator 1965). The negative inotropic effect on the ventricle could be measured only after prestimulation with isoprenaline, while in the atria it showed a direct inhibition of the basal force of contraction (Schrader et al. 1977; Dobson 1978; Belardinelli et al. 1982; Belardinelli and Isenberg 1983a; Böhm et al. 1984). In the ventricle the inhibitory effect of adenosine on isoprenaline-stimulated force of contraction has been attributed to an inhibition of cardiac adenylate cyclase (Schrader et al. 1977; Dobson 1983; Hosey et al. 1984). In guinea pig ventricular myocytes R-PIA caused an inhibition of forskolin-mediated cAMP accumulation (West et al. 1986). Similarly, studies on rat ventricular myocytes showed an inhibition of the isoprenaline-induced elevation of cAMP levels by adenosine receptor agonists (Henrich et al. 1987; Martens et al. 1987). Radioligand binding experiments using membranes prepared from rat ventricular myocytes showed the existence of $A_{1}$ adenosine receptor in ventricular tissue which mediates inhibition of adenylate cyclase (Martens et al. 1987). In atrial tissue, however, the direct negative inotropic effect of adenosine was not accompanied by an alteration in either cAMP or cGMP level (Endoh et al. 1983; Böhm et al. 1984). These authors suggested the existence of an adenosine receptor not coupled to the adenylate cyclase. This suggestion is consistent with previous electrophysiological studies in which it was reported that adenosine caused shortening of the atrial action potential (Johnson and Mc Kinnon 1956; Belardinelli and Isenberg 1983b; West and Belardinelli 1985), an effect attributed to an increased potassium conductance. Jochem and Nawrath (1983) showed that adenosine caused an increase in the rate constant of ${ }^{42} \mathrm{~K}^{+}$efflux in resting guinea pig left atria. Our aim was to clarify via which receptor subtype the atrial action of adenosine is mediated. 
In the present study adenosine analogues caused a stimulation of the ${ }^{86} \mathrm{Rb}^{+}$-efflux rate in isolated left guinea pig atria. The rank order of potency for the tested adenosine derivatives was CCPA $\geq$ R-PIA $\geq$ NECA $\gg$ S-PIA which is consistent with an $A_{1}$ receptor subtype. The differences between the potencies of the three agonists CCPA, R-PIA and NECA are only small in the functional studies and virtually absent in the binding studies. This is somewhat different from classical $A_{1}$ receptor profiles in rat brain membranes (Bruns et al. 1980; Lohse et al. 1984; Lohse et al. 1988), in bovine myocardium (Lohse et al. 1985) and rat ventricular myocytes (Martens et al. 1988), which show a more distinct difference between these agonists. On the other hand, the pronounced stereoselectivity for the PIA enantiomers is characteristic for an $A_{1}$ receptor subtype. Our findings also demonstrate that the adenosine receptor-mediated stimulation of ${ }^{86} \mathrm{Rb}^{+}$efflux is competitively antagonized by the $\mathrm{A}_{1}$ selective antagonist DPCPX.

Radioligand binding studies on membrane preparation of guinea pig atria with $\left[{ }^{3} \mathrm{H}\right] \mathrm{DPCPX}$ showed a saturable binding which further supports the conclusion that the atrial adenosine receptors are of an $A_{1}$ subtype. This finding is in keeping with a recent report of $\mathrm{A}_{1}$ receptor determined by binding studies on porcine atrial membranes (Leid et al. 1988). These authors, however, reported a higher affinity of S-PIA than NECA which is different from our results obtained on guinea pig atria. It can not be excluded that this $\mathrm{A}_{1}$ receptor, in addition to modulating a $\mathrm{K}^{+}$-channel, is also coupled to adenylate cyclase. Endoh et al. (1983) observed that the antiadrenergic effect of adenosine on the force of contraction of rat atria was accompanied by a decrease in the cAMP level.

The $\mathrm{EC}_{50}$-values in the ${ }^{86} \mathrm{Rb}^{+}$efflux experiments were in the same concentration range as the $K_{D}$-values for the low affinity binding sites for agonists. This finding is in agreement with the results of Martens et al. (1988), who reported that the $\mathrm{IC}_{50}$-values of adenosine analogues for the inhibition of the isoprenaline-stimulated cAMP accumulation in ventricular myocytes are in the same concentration range as the $K_{D}$-values for the low affinity state. We conclude that the cardiac effect of adenosine receptor agonists in the atria, as in the ventricle, is mediated via the low affinity state of the receptors.

In summary, our results support the suggestion that there are $\mathrm{K}^{+}$-channel-coupled adenosine receptors in guinea pig atria. They exhibit small differences to the classical adenylate cyclase-coupled $A_{1}$ receptor concerning the agonist affinity profile of the receptor. However, we conclude that this receptor is of the $A_{1}$ receptor family, since it possesses the main characteristics of this receptor type: (1) The $A_{1}$-selective antagonist DPCPX competitively inhibits the adenosine receptor-mediated stimulation of the ${ }^{86} \mathrm{Rb}^{+}$-efflux, (2) radioligand binding showed a saturable high affinity binding of $\left[{ }^{3} \mathrm{H}\right] \mathrm{DPCPX},(3)$ the pronounced stereoselectivity for the two PIA enantiomeres demonstrated in functional and binding experiments.

Acknowledgement. We thank Ms. Heidrun Vogt and Ms. Isolde Villhauer for their technical assistance. This study was supported by the SFB 320 .

\section{References}

Belardinelli L, Vogel S, Linden J, Berne RM (1982) Antiadrenergic action of adenosine on ventricular myocardium in embryonic chick hearts. J Mol Cell Cardiol 14:291-294
Belardinelli L, Isenberg G (1983a) Isolated atrial myocytes: adenosine and acetylcholine increase potassium conductance. Am J Physiol 244:H 734-H 737

Belardinelli L, Isenberg G (1983b) Action of adenosine and isoproterenol on isolated mammalian myocytes. Circ Res 53: $287-297$

Böhm M, Brückner R, Hackbarth I, Haubitz B, Linhart R, Meyer W, Schmidt B, Schmitz W, Scholz H (1984) Adenosine inhibition of catecholamine-induced increase in force of contraction in guinea-pig atrial and ventricular heart preparations. Evidence against cyclic AMP- and cyclic GMP-dependent effect. J Pharmacol Exp Ther 230:483-492

Böhm M, Brückner R, Neumann J, Schmitz W, Scholz H, Starbatty $\mathrm{J}$ (1986) Role of guanine nucleotide-binding protein in the regulation by adenosine of the cardiac potassium conductance and force of contraction. Evaluation with pertussis toxin. NaunynSchmiedeberg's Arch Pharmacol 332:403-405

Brückner R, Fenner A, Meyer W, Nobis T-M, Schmitz W, Scholz $H(1985)$ Cardiac effects of adenosine and adenosine analogs in guinea-pig atrial and ventricular preparations. Evidence against a role of cyclic AMP and cyclic GMP. J Pharmacol Exp Ther $234: 766-774$

Bruns RF, Daly JW, Snyder S (1980) Adenosine receptors in brain membranes: binding of $\mathrm{N}^{6}$-cyclohexyl[ $\left.{ }^{3} \mathrm{H}\right]$ adenosine and 1,3-diethyl-8 $\left[{ }^{3} \mathrm{H}\right]$ phenylxanthine. Proc Natl Acad Sci [USA] 77:5547-5551

De Gubareff T, Sleator W Jr (1965) Effect of caffeine on mammalian atrial muscle and its interaction with adenosine and calcium. $\mathrm{J}$ Pharmacol Exp Ther 148:202-214

Dobson JG (1978) Reduction by adenosine of the isoprenalineinduced increase in cyclic adenosine $3^{\prime}-5^{\prime}$-monophosphate formation and glycogen phosphorylase activity in rat heart muscle. Circ Res 43:785-792

Dobson JG Jr (1983) Mechanism of adenosine inhibition of catecholamine-induced responces in the heart. Circ Res 52:151 160

Drury AN, Szent-Györgyi (1929) The physiological activity of adenine compounds with special reference to their action upon the mammalian heart. J Physiol (Lond) 68:213-237

Endoh M, Maruyama M, Tairo NJ (1983) Modification by islet activating protein of direct and indirect inhibitory actions of adenosine on rat atrial contraction in relation to cyclic nucleotide metabolism. J Cardiovasc Pharmacol 5:131-142

Evans DB, Schenden J, Bristol JA (1982) Adenosine receptors mediating cardiac depression. Life Sci 31:2425-2432

Gerstheimer FP, Mühleisen M, Nehring D, Kreye VAW (1987) A chloride-bicarbonate exchanging carrier in vascular smooth muscle of the rabbit. Pflügers Arch 409:60-66

Henrich M, Piper HM, Schrader J (1987) Evidence for adenylate cyclase-coupled $\mathrm{A}_{1}$-adenosine receptors on ventricular cardiomyocytes from adult rat and dog heart. Life Sci $41: 2381-2388$

Hollander PB, Webb JL (1957) Effect of adenosine nucleotides on the contractility and membrane potentials of rat atrium. Circ Res 5:349-353

Hosey MM, Mc Mahon KK, Green RD (1984) Inhibitory adenosine receptors in the heart: Characterization by ligand binding studies and effects on $\beta$-adrenergic receptor stimulated adenylate cyclase and membrane protein phosphorylation. J Mol Cell Cardiol 16:931-942

James TN (1965) The chronotropic action of ATP and related compounds studied by direct perfusion of the sinus node. J Pharmacol Exp Ther 149:233-247

Jochem G, Nawrath H (1983) Adenosine activates a potassium conductance in guinea pig atrial heart muscle. Experientia 39:1347-1349

Johnson EA, Mc Kinnon MG (1956) Effect of acetylcholine and adenosine on cardiac cellular potentials. Nature (Lond) 178:1174-1175

Kurachi Y, Nakajima T, Sugimoto T (1986) On the mechanism of activation of muscarinic $\mathrm{K}^{+}$channels by adenosine in isolated 
atrial cells: involvement of GTP-binding proteins. Pflügers Arch 407:264-274

Leid M, Frankin PH, Murray TF (1988) Labeling of $A_{1}$ adenosine receptors in porcine atria with the antagonist radioligand 8-cyclopentyl-1,3- $\left[{ }^{3} \mathrm{H}\right]$ dipropylxanthine. Eur J Pharmacol 147:141-144

Lohse MJ, Lenschow V, Schwabe U (1984) Two affinity states of $R_{i}$ adenosine receptors in brain membranes: analysis of guanine nucleotide and temperature effects on radioligand binding. Mol Pharmacol 26:1-9

Lohse MJ, Ukena D, Schwabe U (1985) Demonstration of $R_{i}$ type adenosine receptors. in bovine myocardium by radioligand binding. Naunyn-Schmiedeberg's Arch Pharmacol 328:310316

Lohse MJ, Klotz K-N, Lindenborn-Fotinos J, Reddington M, Schwabe U, Olsson RA (1987) 8-Cyclopentyl-1,3-dipropylxanthine (DPCPX) - a selective high affinity antagonist radioligand for $A_{1}$ adenosine receptors. Naunyn-Schmiedeberg's Arch Pharmacol 336:204-210

Lohse MJ, Klotz K-N, Schwabe U, Cristalli G, Vittori S, Grifantini M (1988) 2-Chloro- $\mathrm{N}^{6}$-cyclopentyladenosine: a highly selective agonist at $A_{1}$ adenosine receptors. Naunyn-Schmiedeberg's Arch Pharmacol 337:687-689

Martens D, Lohse MJ, Rauch B, Schwabe U (1987) Pharmacological characterization of $A_{1}$ adenosine receptors in isolated rat ventricular myocytes. Naunyn-Schmiedeberg's Arch Pharmacol 336:342-348

Martens D, Lohse MJ, Schwabe U (1988) [ $\left.{ }^{3} \mathrm{H}\right]-8$-Cyclopentyl-1,3dipropylxanthine binding to $A_{1}$ adenosine receptors of intact rat ventricular myocytes. Circ Res 63:613-620

Peterson GL (1977) A simplification of the protein assay method of Lowry et al. which is more general applicable. Anal Biochem $83: 346-356$

Schrader J, Baumann G, Gerlach E (1977) Adenosine as inhibitor of myocardial effect of catecholamines. Pflügers Arch 372:2935

Trussell LO, Jackson MB (1987) Dependence of an adenosine activated potassium current on a GTP binding protein in mammalian central neurons. J Neurosci 7:3306-3316

West GA, Belardinelli L (1985) Correlation of sinus slowing and hyperpolarization caused by adenosine in sinus node. Pflügers Arch 403:75-81

West GA, Isenberg G, Belardinelli L (1986) Antagonism of forskolin effects by adenosine in isolated hearts and ventricular myocytes. Am J Physiol 250:H 769 - H 777

Received June 20, 1989/Accepted September 15, 1989 